\title{
Czarist Missionary Contact with Central Asia: Models of Contextualization?
}

David M. Johnstone

George Fox University, djohnsto@georgefox.edu

Follow this and additional works at: http://digitalcommons.georgefox.edu/student_life_works

Part of the Islamic World and Near East History Commons, Missions and World Christianity Commons, and the Slavic Languages and Societies Commons

\section{Recommended Citation}

Johnstone, David M., "Czarist Missionary Contact with Central Asia: Models of Contextualization?" (2007). Staff Publications Student Life. Paper 13.

http://digitalcommons.georgefox.edu/student_life_works/13 


\title{
Czarist Missionary Contact with Central Asia: Models of Contextualization?
}

\author{
David M. Johnstone
}

$\mathbf{Y}_{\mathrm{r} \text { e }}^{\mathrm{e}}$ ears ago I asked field-workers from the central Asian republics of the former Union of Soviet Socialist Republics why there was not greater cooperation with the Russian Orthodox Church in attempts to establish indigenous churches among the Muslim peoples of these regions. Their immediate reply was that the Orthodox were too heavily enmeshed with czaristimperial policies. ${ }^{1}$ Orthodox involvement would be too great a liability. Memories of Orthodox priests marching before the czar's armies were still too vivid for many central Asian Muslims.

The czars had pursued aggressive expansion projects; the Orthodox Church acquiesced to the imperial will. This was a simple interpretation of history. Yet was it fair to condemn and so completely dismiss such an enduring church community?

Despite the long history of enmity between Russians and their Muslim neighbors, there were also high points in the history of Russian Orthodox relations with the Muslims of central Asia. Although the Western church knows little of these ventures, Russian Orthodoxy in fact has a rich missionary heritage. ${ }^{2}$ There have been instances of great courage, passion, and cultural sensitivity in Orthodox attempts to bring the Gospel to the Muslim peoples. I outline here some of the context and features of these missionary endeavors.

\section{Historical Background}

Russia's long history of interaction with Islam began with the Mongol conquests of Russian territory (ca. 1240). It was from this period that the Russians and Europeans knew Mongols as the Tatars (or sometimes "Tartars")..$^{3}$ Over time, the Mongols, or the Golden Horde, became predominately Muslim, and thus the words "Tatar" and "Muslim" becamesynonymous in the Russian mind. The Russians endured as Tatar vassals. Occasionally they rebelled, but most of the time they acquiesced, for they knew that destruction awaited any act of disobedience.

Eventually devastation was unavoidable. It arose not in response to disobedience but due to the Tatars' ferocity. Timur the Great (1336-1405), or Tamerlane, conquered central Asia and dreamed of restoring the glory days of Islam. As a fanatical Muslim he longed for the destruction of the infidel, eventually wreaking havoc over much of the land lying between China and the Mediterranean. ${ }^{4}$ His trademark became great pyramids of victims' skulls that he built outside the towns he vanquished. ${ }^{5}$

Between the fourteenth and sixteenth centuries the Golden Hordedivided into numerous principalities, eventually becoming the separate ethnic groups known as the Crimean Tatar, Volga Tatar, Uzbek, Kazakh, and other peoples. ${ }^{6}$ During this same period, the Russians began to centralize their strength and to assert their own military prowess.? Not until 1480, however, could they finally cast off the Tatar yoke. From out of the ashes of Tatar occupation arose Muscovite Russia.

With Ivan IV (1533-84), known as the Terrible, there was a reversal of the trend of losing territory to the Tatars. Russian troops

David M. Johnstone is Associate Dean of Students at George Fox University, Newberg, Oregon. His research has focused on non-Western Christianity and cross-cultural dynamics. began penetrating the open steppes and occupying Muslim soil. Ivan's first major contest was to attack the crumbling Tatar power still entrenched on the banks of the Volga. In 1552 he led two campaigns in which he captured Kazan and "brought the whole Volga basin down to the Caspian Sea into the Russian Empire."8 In 1554-55 the Tatar stronghold of Astrakhan was overthrown, and by 1581 the conquest of Siberia was under way. ${ }^{9}$

Elsewhere, a century earlier, the Ottoman Turks had stormed and finally conquered Constantinople(1453). After this Orthodox loss, there developed among Russians the popular view that Muscovite Russia was to take responsibility for the leadership of Orthodox Christendom. The grand prince of Moscow began to be seen as the agent of God on earth. Muscovite Russia was to have a vital place in the history of Christendom: "Two Romes have fallen, but the third stands fast; a fourth there cannot be." The notion of divine favor encouraged subsequent princes to call themselves "czar," the equivalent of the Byzantine basileus and the Roman caesar. This action further advanced the assertion that Moscow had become the Third Rome. ${ }^{11}$

Ivan IV became the "militant representative of the idea of sacred autocracy."12 The true czar was to be the "preserver of the holy Orthodox Christian faith ... [keeping] vigil over the Christ possessing people. ${ }^{13}$ This assertion implied that all clergy were to subordinate themselves to the sovereign's will and, by insinuation, made the czar responsible for the ultimate care and direction of both church and nation.

This new posture of the state came into direct conflict with the church in 1568. At this time, Philip, metropolitan of Moscow (1566-68), publicly rebuked Ivan for his ongoing killing and oppression of innocent people. Philip's call for repentance was perceived as a direct challenge to the czar's authority. Within six months Ivan had Philip deposed, imprisoned, and murdered. ${ }^{14}$

One of the severest blows to the Russian Orthodox Church came from Peter the Great (1682-1725). Peter believed that the head of the church, the patriarch of Moscow, "posed a serious obstacle to his vast reforms ... of Russian life." 15 Upon the death of the patriarch in 1700, Peter did not convene a council in order to elect a replacement. Within a few months he dissolved the ecclesiastical courts and bureaucracy. After decades of maneuvering and scheming, in 1721 Peter established the Reglament, or the Holy Directing Synod. ${ }^{16}$ In establishing the synod, Peter asserted that "as the supreme Sovereign, [he] had the divine authority for establishing and correcting the faith, and therefore he undertook to put order in the Russian Church by the present statute." As czar, he believed that he was to have "absolute control, or jurisdiction, over all spiritual interests." 17

Appointments to ecclesiastical positions were decided by power politics and had very little to do with the spiritual condition of each candidate. Catherine II (1762-96) appointed men to the position of procurator of the Holy Synod who were openly hostile to Christianity. She appropriated vast tracts of monastic and church lands. More than half of the monastic houses were closed, and the number of monks was strictly limited. When bishops rose up in protest, many were defrocked, imprisoned, or murdered. ${ }^{18}$ 


\section{Beginning of Orthodox Missions (1550-ca. 1800)}

From the sixteenth century the Russian Empire became more assertive and expansionist. The conquest of Kazan and Astrakhan opened the door to localized evangelism among the people of Siberia by exceptional men. ${ }^{19}$ History begins to identify pioneer missionaries who initiated work among the Tatars and their kin. It was difficult work that encountered (1) the cultural diversity of numerous languages, lifestyles, and belief systems; (2) the vast barren lands of Siberia; (3) the nomadic life of the Tatars; (4) the rigors of the climate; (5) the hostility of a conquered people; and (6) the depression and frustration of long periods with little success. ${ }^{20}$ Despite these obstacles, these pioneers persevered in presenting the Gospel.

In 1555 Bishop Gouri was sent to work in defeated Kazan. In nine years of labor, Gouri saw "thousands of Tartars" converted to Christianity. ${ }^{21}$ His methodology was to teach in both church and home, build monasteries and churches, establish schools, and provide refuge and protection to the oppressed. His associate and successor, Germanus (d. 1569), who had been taken cap- domination of the church by the state in forcing it to be a "civilizing" factor in the newly colonized regions. ${ }^{28}$

In 1773 Catherine adopted a new policy toward the Muslims of her empire. ${ }^{29}$ Trying to avoid rebellions, she sought to win the goodwill of her Muslim subjects. Reversing earlier imperial policies, she had new mosques built, and benefits were no longer offered to new Christian converts. ${ }^{30}$ This change led to a mass exodus of superficial converts back to Islam. ${ }^{31}$

Eugene Smirnoff identifies the period from 1756 to 1824 as a period of stagnation for Russian missions. ${ }^{32}$ Missionaries lacked knowledge of the indigenous languages, and new converts were enticed by rewards of money or exemption from taxes. ${ }^{33}$ Missionary efforts lacked an overall organizational structure and there was no coherent theory to guide their endeavors.

\section{Nineteenth-Century Missionary Ventures}

In 1828 the Holy Synod of the Russian Orthodox Church became quite concerned about the apostasy that was widespread in regions where the government was using "Christianization to produce Russification." ${ }^{34}$ Konstantin P. Pobiedonostsev (1827-1907), chief procurator of the synod, wrote toward the end of the nineteenth century:

$S|B E R| A$
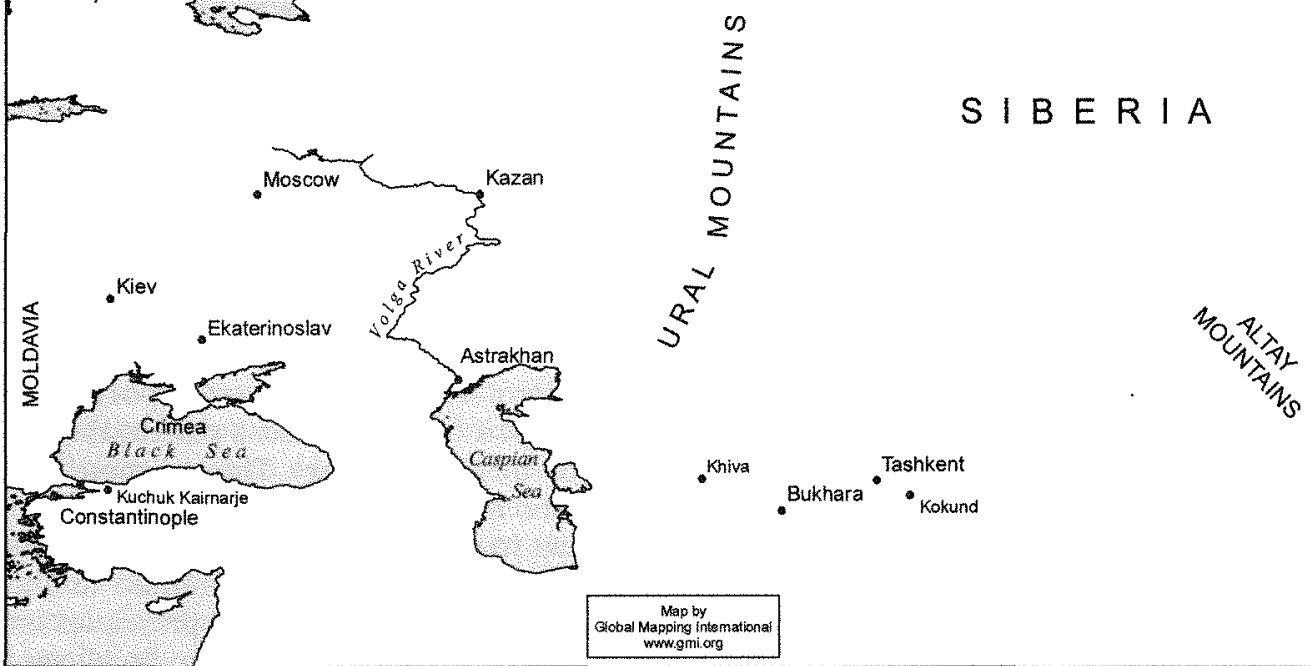

The conversion of the Tartars and natives to the Orthodox faith en masse having been only outward and ceremonial, did not at first present any difficulties. ... The efforts of the Government for the confirmation of the faith was limited to outward measures of prescripts, rewards and punishments. Meanwhile, in the course of time Mahometanism grew stronger in the Tartar settlements, with a fully developed system of dogmatic teaching, and with a complete organization of clergy and schools near mosques; the spirit of fanatical propaganda increased under the influence of intercourse and contact with the Central-Asian centres of Is-

tive by the Crimean Tatars, knew their language and faith well. ${ }^{22}$ Germanus is said to have "dedicated his life to the conversion of the Tartars." 23

Russian expansion into the Crimea and central Asia linked conversion with colonization. Converts were extended favor and benefits by the government. ${ }^{24}$ A system of bribery was established that was not conducive to creating mature believers. Under Peter the Great, church initiatives were placed under state restrictions. In 1685 Peter endorsed the extension of a mission to the Chinese, as well as encouraged the establishment of further missions to Muslims. ${ }^{25}$ Some have suggested that his encouragement was "politically rather than religiously motivated." 26 Peter was in the process of building a buffer zone between Russian territory and the threats from the Ottoman Empire. As he expanded into the southern steppes, missionary work was used as a way to assimilate and penetrate the new regions.

In 1743, under orders from Elizabeth (1741-62), 418 of the 536 mosques in Kazan were destroyed. "In 1744-1747, 838 conversions from Islam were reported, and in 1748-1752, 7,535."27 The circumstances of these conversions are suspect, for in the reigns of Elizabeth and Catherine II, there was an increasing lam. A falling off en masse of the old-baptized Tartars commenced, they having nothing in common either in spirit or custom with the Orthodox Church, but, on the contrary, being connected in both with the ordinary conditions of the Mussalman population..$^{35}$

Lack of interest on one side, compounded by Muslim growth on the other, caused the Holy Synod to become concerned. It thus began appealing for missionaries.

Makarii Glukharev. One of the most unlikely candidates was Makarii Glukharev (1792-1849). ${ }^{36}$ Although he seemed physically unsuited for any frontier missionary work, Glukharev chose to go to a particularly difficult region - the mountainous terrain of the Altai Range. Born the son of a devout parish priest, Glukharev excelled scholastically all his life. His outstanding record provided him with entrance into the Ecclesiastical Academy. In 1817 he took a professorship at the Ekaterinoslav Seminary, and in 1821 , at the age of twenty-nine, he became rector of Kastroma Seminary. ${ }^{37}$

While at the seminary in Ekaterinoslav he encountered monks who were disciples of Paissy Velitchkovsky (1722-94), 
of Moldavia. Velitchkovsky was notable in initiating a major spiritual revival within the Russian Church in the Hesychast tradition. ${ }^{38}$ Glukharev's encounter with this movement was a major crossroads for him. Resigning his position as a rector, he withdrew into the monastic community at Kiev. Not finding enough seclusion at this place, he gradually moved further into the deserts. ${ }^{39}$ It was there that the 1828 appeal from the Holy Synod found him.

Responding quickly, Glukharev was in the Altai Mountains of southwestern Siberia by $1830 .{ }^{40} \mathrm{His}$ team drew up a compact, modeling itself on the early Christian community in Jerusalem: "Let it be our rule that we should possess everything in common, money, food, clothes, books and everything else, and let this be a means of facilitating our inspiration towards unanimity." ${ }^{\prime \prime 1}$ This goal has been described as being "an apostolic rather than

\section{When preaching proved to be inadequate, Glukharev set out to become a servant to the nomads.}

a monastic ideal." ${ }^{42}$ The unanimity of vision displayed by this small team became part of their strategy for reaching out to the tribes of central Asia.

Initially they spent their time learning the languages of the warlike, nomadic Tatar, Kalmyk, and other tribespeople. Glukharev himself soon began to master the Telengut dialect, the most prevalent conversational language of the region. ${ }^{43} \mathrm{He}$ also busied himself translating the Scriptures and portions of the liturgical books in order to perform services in the vernacular. ${ }^{44}$ Traveling for many months at a time, he frequently visited the nomadic villages. His simple approach was "to preach to large gatherings about the main events of salvation." 45 Yet there was little response from the Altaic tribesmen. Glukharev later wrote: "A faint-hearted missionary would have concluded that these people were not ready for Christianity. Who am I to judge a people's unreadiness to receive the universal faith in Jesus Christ, who shed His blood on the Cross and tasted death for all men and for their salvation? No people exist among whom God does not recognize His own; there are no depths of ignorance or darkness which the Lord cannot penetrate." ${ }^{\prime 6}$

Convinced of his call and determined to persevere, Glukharev set out to change his methodology. When preaching proved to be inadequate, he set out to become a servant to the nomads, especially in the areas of medicine and hygiene. In this manner Glukharev eventually introduced thesmallpox vaccination to the Altai peoples. In terms of hygiene, he not only taught through words but also modeled what was important. By going into local homes and doing the cleaning himself, he began to demonstrate the very theology of mission that he valued. "To sweep the floor as a humble servant is to identify oneself with Christ, to bear witness to Him in a way which is more authentic than speeches." 47

In 1839 he published a volume outlining his theology and incorporating some of his ideas on missionary training. This document, Thoughts on Means of the Most Successful Expansion of the Christian Faith Among the Jews, Mohammedans, and Heathens in the Russian Empire, charted his thinking on the creation of a missionary study center in Kazan. At this facility he recommended a program that included medicine, nursing, and agriculture.
He himself had been prepared by taking university courses in natural science, anatomy, and botany. ${ }^{48}$

On the field, Glukharev was very cautious in admitting the nomadic tribesmen to baptism. This was a time when rewards were once again extended both to new converts and to the missionary who performed many baptisms. Glukharev was not interested in prizes or in numbers. ${ }^{49}$ Over the course of thirteen years he baptized 650 adults. ${ }^{50}$ Yet Glukharev saw baptism as only the start of his responsibilities. As Smirnoff explains, "He constantly maintained that the work of conversion only begins with baptism' and therefore took even more care of a convert after baptism than before." $" 1$

Because of the hostility of unbelieving family and neighbors, Glukharev established Christian settlements for the new converts, with hospitals and schools also being founded under his initiative. By the turn of the century there were " 25,000 converts, 188 Christian villages, 67 churches with services entirely in the vernacular languages. "52 The Altai mission continued to flourish under the oversight of Vladimir Petrov and other successors. ${ }^{53}$ By Zernov's estimate, "Twenty-five thousand of the forty-five thousand inhabitants of the Altai region became Christians." 54

Makarii Glukharev was a man of stature equal to many of the great pioneer missionaries of the Protestant movement. His courage, tenacity, and creativity enabled him to impact a region that was not only spiritually a challenge but also physically harsh and merciless. He followed wise missionary principles that were widely emulated by others. Glukharev was a man with a passion for God and longed to see his own people, the Russians, reaching out to those around them with the Gospel. Unfortunately, he came to realize that "the Russian masses were only superficially Christian, and therefore inadequate for the great apostolic task God had in store for them." 55

Nikolai Ivanovitch Ilminskii. A younger contemporary of Glukharev's, Nikolai Ilminskii (1822-91) had a penetrating effect on Russian Orthodox mission strategy. Though more of a scholar than a field-worker, he did not shy away from the dynamics facing those trying to reach the Muslims of Russia. As a theorist, linguist, orientalist, and layman committed to and supported by the established church, he outlined principles for cross-cultural evangelism that appear to be amazingly relevant to the modern period.

As early as 1847 he began to reflect upon the principles he later formulated and developed. At this time he began to translate portions of Scripture and other liturgical works into the colloquial languages of the Tatars. ${ }^{56}$ The previous year he had graduated from the Ecclesiastical Academy of Kazan and was offered the position of professor of Oriental languages. ${ }^{57}$ Unfortunately, the local archbishop questioned his loyalties and suspected him of Islamic inclinations. Ilminskii was dismissed and headed for the frontiers, where he took up a clerkship. This position enabled him to improve his growing linguistic skills and deepen his knowledge of languages used among the Muslim peoples. ${ }^{58}$

Ilminskii continued his translation work, having been chosen to be part of a committee translating the Russian Scriptures and liturgical books into Tatar. The committee's underlying principle was to eschew use of the local vernaculars and to translate into a literary language indebted to qu' ranic Arabic. ${ }^{59}$ In 1851 he set out for the Near East in order to perfect his knowledge of Arabic. He resided for many months in Constantinople and Lebanon and even enrolled clandestinely in a Muslim university in Cairo in order to expand his knowledge of Arabic and Persian. ${ }^{60}$

Upon his return in 1853 and the publication of these newly 
translated works, Ilminskii realized that the intended objective of the new Scriptures would not be realized. He concluded that the literary languages used by the Tatars and their neighbors, which were permeated with Arabic words infused with Islamic meaning and qur'anic imagery, were inappropriate for communicating the Gospel. ${ }^{61}$ In 1858 Ilminskii wrote that "in order to serve effectually for Christian enlightenment of the Tartars, the translations ought to be made in a language entirely comprehensible to them, that is in a conversational language, because they have no written language.... In order to sever completely the tie between the Christianised Tartars and Mahometanism, the alphabet itself employed in question should be Russian, adapting it to the Tartar sounds." ${ }^{\prime 2}$

Ilminskii believed that creating a new written script for the Tatar languages would enable translators to use words that did not lead the reader back to Islam. He was convinced that "the slow progress of the Gospel among the Tartars was due to the use of the classical language into which both the Scripture and other works were translated. They could not follow or understand them and, surrounded by masses of Muslims, they lapsed. ${ }^{\prime 63}$ In the situation Ilminskii faced, the liturgical services among the Tatar were in Slavonic. Their Scriptures were in a different but also unfamiliar language. Compounding these factors was the lack of any native Tatar clergy. The Tatar were, as Stamoolis writes, "ripe for Muslim counterpropaganda." ${ }^{64}$

Once again Ilminskii returned to central Asia, and in 1861 he was offered the chair of Turkic languages at the University of Kazan. ${ }^{65}$ With others, he began laying out his strategic plans for reaching the Muslims of the Russian Empire. ${ }^{66}$ Ilminskii's first assertion was that a mission must preach to each tribe in its common conversational language. Accordingly, the Scriptures and the Orthodox liturgical books must be translated into the vernacular of each people. ${ }^{67}$

By using the colloquial speech of the Tatars both in translation of the Scriptures and in the liturgy, Ilminskii set out to break the link with Islam. He produced a phonetic script easily accessible by the common people. ${ }^{68}$ Then, using Russian characters, he eliminated the use of Arabic script. Setting out to verify the impact and relevance of his thesis, he presented some of his new vernacular translations to local Tatar boys. They "understood his translation of the Gospel narrative of the Pool of Bethesda, and even corrected some of his expressions. A white-haired old man amongst the baptized Tartars, hearing the prayers in his native tongue, fell on his knees before the icon, and with tears in his eyes thanked God for having vouchsafed to him at least once in his life to pray as he should." ${ }^{69}$

In his quest to produce high-quality material, Ilminskii sought the direct aid of the indigenous peoples. "It is essential that the final touches should be put to the translations, with the assistance of natives by birth, because a Russian, as I know by my own experience, having occupied myself with Tartar translations for about thirty years, cannot know all the subtleties, shades and psychological depths of a foreign tongue." ${ }^{70} \mathrm{He}$ was not just trying to create new and intelligible translations; his aim was "the formation of a specific Christian Tartar language in opposition to an Islamic one."71

Related to this literary strategy was the establishment of a network of schools with lessons carried out in the indigenous languages of the tribes. ${ }^{72}$ From his Near Eastern experience and his intimate knowledge of Tatar daily life, Ilminskii discerned that the strength of Islam lay in its system of mosque schools, in which Tatar and other Muslim boys were taught the essentials of Islam. ${ }^{73}$ His schools provided an alternative to the Muslim edu- cational system. Because of the needs for highly fluent teachers and priests, Ilminskii recommended that indigenous educators and clergy be trained. ${ }^{74}$ These individuals would be brought in with the intention of replacing the Russians as quickly as possible. ${ }^{75}$ In response to these needs, the missionary brotherhood of St. Gouri was established in 1867 in order to publish the newly translated works and to establish schools. ${ }^{76}$

Alongside his call for the use of the vernacular and the use of indigenous clergy and teachers, Ilminskii set forth one more radical principle of missionary work: each mission should work toward no longer being reliant on Russian funds and missionaries. As indigenous clergy were trained and the Russians withdrawn, the mission should learn to become self-sufficient. This was a strong challenge to the status quo, for the Russian missionaries tended to respond to the nationals "as children to be educated as long as possible." 77

Ilminskii was able to see remarkable success. The schools opened under his direction were deemed of high enough caliber for the graduates to be accepted for ordination. Forty-four Tatar, ten Chuvash, nine Cheremi, and two Votiak were ordained in his lifetime..$^{78}$ The Orthodox divine service was translated into Tatar, which proved to be one of the most effective missionary methods. ${ }^{79}$

The movement initiated by Ilminskii survived his death. Many others successfully implemented his methodology, slowing the tide of converts toward Islam. ${ }^{80}$ Ilminskii provided a sign of hope in a time when the church was facing many problems, both at home and on the frontiers.

Other Orthodox missionary activity. Orthodox monks and priests also penetrated other regions of the empire's frontiers. In these regions the work among Muslims tended to focus heavily on education and the creation of "asylums" of refuge for orphans and other oppressed individuals. The educational aspects of each mission played a major role in their attempt to present the Gospel. According to Smirnoff, "The entire history of Russian missions is in reality nothing else but the history of the Christian instruction of the natives in Russia.. ${ }^{81}$

The establishment of the Russian Missionary Society in 1865 further consolidated the work of the Orthodox Church. It provided guidance and materials for the individual missions

\section{By using the colloquial speech of the Tatars in translation and in the liturgy, Ilminskii set out to break the link with Islam.}

and tried to awaken the interest of Orthodox Russians in their church's missionary enterprises. ${ }^{82}$

Part of Ilminskii's legacy was his emphasis on the preparation of missionary candidates. In 1854 the Kazan Ecclesiastical Academy created a missionary department ${ }^{83}$ It was a partial fulfillment of Gloukharev's dream for a missionary training school. ${ }^{84}$ However, because the course of work was mingled with the general academic requirements of the institution, missionary preparation became unfocused and inadequate. In 1889, because of this unsatisfactory state of affairs, Professor V. V. Mirotvortzeff of the academy established a two-year missionary program. By 
1897 it was meeting in the Spao-Preobrajensky ("Transfiguration of Our Savior") Monastery in Kazan, forming a separate educational facility. ${ }^{85}$

Thenineteenth century was a high point for Russian Orthodox missionary activity. In spite of the aggressive work by the czars of empire building, many desired to genuinely present and offer the good news of Christ to the unbelieving peoples of Russia.

\section{Conclusions}

The tenacity, perseverance, and courage of these Orthodox missionaries to central Asia become even more incredible when we consider the obstacles they faced. ${ }^{86}$ First, the topography was unbelievably vast, with a climate to match its size. In some regions one missionary would be responsible for traveling circuits of over 1,000 kilometers. ${ }^{87}$ They would journey in the extremes of freezing temperatures of the Altai or in the scorching heat of the Uzbek deserts. This itineration was part of their attempts to minister to highly nomadic tribes. The vast territories covered by these nomadic tribes sometimes required the missionaries to literally hunt the nomads by following their tracks.

Second, the diversity of languages and cultures posed a tremendous challenge. The numbers of Muslim people groups within the Russian sphere was (and still is) numerous. As a sampling, there were Tatars, Uzbeks, Kazaks, Kirghiz, Karakalpaks, Uighurs, Altai, and Tajiks, all needing the presence of indigenous churches.

The third significant obstacle was specific to those working among Muslims. Muslim propaganda was highly organized and could become extremely violent. Regions such as the Caucasus and the Khanate of Bukhara were especially strong, with highly organized Sufi movements and Islamic training centers. While martyrdoms among missionaries were rare, violence directed at converts was always a possibility. ${ }^{88}$

The fourth major hurdle was the scarcity of mission stations, resources, and manpower. If one considers that among the 800,000 Kirghiz, there were only nine stations with twenty-eight work- ers, it is easy to imagine the challenges. To further complicate matters, the missionaries were responsible for the spiritual care of the Russian congregants of their diocese as well. For instance, the Kirghiz regions of Semipalatinsk and Akmolinsk had 2,853 Orthodox congregants. Of these, 2,503 were Russian, while 350 were indigenous to the region. ${ }^{89}$ These scenarios multiplied the burden and taxed the material, spiritual, and emotional resources of the missionaries. Despite these challenges, the Orthodox missionaries persevered and "laboured greatly and seriously for the enlightenment" of the peoples in the Russian Empire. ${ }^{90}$

In evaluating the actions of the pre-Revolutionary Russian Orthodox missionaries and strategists, one must remember that these concepts were created without the cross-pollination present in the Western missionary movements of the same era. In the West, men such as Henry Venn, Rufus Anderson, and later John Nevius, Robert Speer, and others provided much innovation in missionary thinking and strategy. The Orthodox were not a part of this creative interaction. This fact alone makes men such as Makarii Glukharev and Nikolai Ilminskii more impressive.

The historical enmity between Russians and many of the Muslim peoples persists in certain regions. As tradition plays a major role in the Russian Orthodox worldview, however, the Orthodox should be encouraged to reflect upon alternate ways of responding to Muslims. As believers they should be challenged to examine their heritage and emulate the kindness extended to Muslims modeled by Gouri, Glukharev, Ilminskii, and others. Traditional enmity could be transformed through attempts to reflect Christ's character through reconciliation and grace.

Finally, we must recognize that non-Russians contemplating work in the former Soviet central Asia cannot remove themselves from contact with the Orthodox Church. Knowledge of significant historical Orthodox figures and their thinking will be of great assistance in developing relationships and appreciation for Orthodoxy. Orthodox missionaries have blazed many of the trails currently being penetrated by other field-workers. We would do well to remain humble and learn the wisdom that these earlier missionaries gathered from their journeys.

\section{Notes}

1. Oleg Kobtzeff, "Ruling Siberia: The Imperial Power, the Orthodox Church, and the Native People," St. Vladimir's Theological Quarterly 30, no. 3 (1986): 269-72.

2. Anastasios Yannoulatos, "Discovering the Orthodox Missionary Ethos," Martyria Mission: The Witness of the Orthodox Churches Today, ed. Ion Bria (Geneva: WCC Publications, 1980), pp. 21-22.

3. For discussion of the origin of the name "Tatar" and abrief explanation of the ethnic history of this group, see James G. Nutsch, "Tatars," in The Modern Encyclopedia of Russian and Soviet History, ed. Joseph L. Wieczynsk (Gulf Breeze, Fla.: Academic International Press, 1976-2000).

4. Once when $I$ was with a group viewing Tamerlane's tomb in Samarkand, the Intourist guide related to us that in the early 1940 s Soviet archaeologists desired to open his tomb in order to verify the authenticity of the remains. The Uzbek people arose in great fear, cautioning the authorities that a curse lay upon the tomb that threatened to release Tamerlane's spirit, spreading destruction over the earth. Scoffing at this superstition, the archaeologists received permission from Stalin himself. The day they opened the tomb, Hitler's armies invaded the USSR.

5. Samuel Hugh Moffett, A History of Christianity in Asia, vol. 1, Beginnings to 1500 (San Francisco: HarperSanFrancisco, 1992), p. 486.

6. Ira M. Lapidus, A History of Islamic Societies (Cambridge: Cambridge Univ. Press, 1988), p. 419.

7. John Lawrence, A History of Russia, 7th ed. (New York: Meridian Books, 1993; orig. pub., 1957), pp. $88 \mathrm{ff}$.

8. Gary Hobin, "Appendix C: A Brief History of Islam, with Special Reference to Russia and the Soviet Union," in An Ethnographical Dictionary of the Russian and Soviet Empires (Westport, Conn.: Greenwood Press, 1994), p. 764.

9. Nadia Diuk and Adrian Karatnycky, The Hidden Nations: The People Challenge the Soviet Union (New York: William Morrow, 1990), p. 169.

10. Nicolas Zernov, Eastern Christendom: A Study of the Origin and Development of the Eastern Orthodox Church (London: Weidenfeld \& Nicolson, 1961), p. 140. See also William-Kenneth Medlin, Moscow and East Rome: A Political Study of the Relations of Church and State in Muscovite Russia (Westport, Conn.: Hyperion Press, 1981; orig. pub., 1952), pp. $92 \mathrm{ff}$.

11. This notion of a third Rome was revived in the early periods of the nineteenth century to provide a foundation for justification of the empire's policies of civilizing and Christianizing Siberia. See Kobtzeff, "Ruling Siberia," pp. 274-75.

12. Zernov, Eastern Christendom, p. 143.

13. Medlin, Moscow and East Rome, p. 94.

14. Nicolas Zernov, The Russians and Their Church, 3rd ed. (London: SPCK, 1978; orig. pub., 1945), pp. 59-61.

15. Medlin, Moscow and East Rome, p. 216.

16. See ibid., pp. 216ff., for the details regarding Peter's intrigue.

17. Ibid., pp. $219,222$.

18. Timothy Ware, The Orthodox Church (Harmondsworth: Penguin Books, 1963), p. 127. 
"The PbD in Intercultural Studies program trains students to be both theologically astute and anthropologically sensitive so that they can better apply the Word of God critically in any buman or cultural context. The faculty are all experts in their own right, and they contribute to the richness of the program not only by their theological insigbts but also by their years of significant intercultural experience. The diversity of the students, botb in termo of their cultural background and their crosd-cultural ministry experience, creates a unique community where theological and misoiological thinking is forged in a bighly stimulating context."

- Doctoral dtudent How-Chuang Cbua came to

Trinity after four years of churcb planting work as a misoionary in Japan.
Our full-time Mission and Evangelism faculty members include:

Richard R. Cook, PhD Mission History and Global Christianity

Paul G. Hiebert, PhD

Anthropology and Missiology

Harold A. Netland, PhD

Religion and Intercultura/ Studies

John W. Nyquist, PhD

Evangelism and Discipleship

Craig Ott, PhD

Church Planting, Contextualization

James F, Plueddemann, PhD

Leadership and Education

Robert J. Priest, PhD

Anthropology and Intercultural Studies

Tite Tiénou, PhD

Theology of Mission, Ethnicity

\section{Trinity Evangelical Divinity School}

Ask tough questions

Expand your understanding

Explore different perspectives

Experience relevant ministry

\section{Is God leading you}

\section{towar intercilura inistri?}

At rinity we offer several degree options to hel p you deepen your

theologreal understanding cultural insights and missionary skills for strategic

cross cultural ministries both globally and locally. Trinity's faculty combine international experience

with academic excellence to help you reflect, explore, and grow to achieve your educational and ministry goals.

Intercultural degree programs at Trinity indude:

- MDiv with a focus on Cross-Cultural Ministry - MA in Intercultural Studies or Evangelism

- ThM in Mission and Evangelism • PhD in Intercultural Studies • DMin in Missions and Evangelism

Contact our Office of Admission today: $\mathbf{8 0 0 . 5 8 3 . 6 6 5 4}$

Trinity Evangelical Divinity School | 2065 Half Day Road, Deerfield, IL 60015 | www.teds.edu 
19. Kobtzeff, "Ruling Siberia," p. 274.

20. David N. Collins, "Colonialism and Siberian Development: A CaseStudy of the Orthodox Mission to the Altay, 1830-1913," in The Development of Siberia: People and Resources, ed. Alan Wood and R. A. French (New York: St. Martin's Press, 1989), p. 58.

21. Though he was not writing for an academic audience, Eugene Smirnoff asserts that most careful attention was given to data verified from "the Reports of the Chief Procurator of the Most Holy Synod, in the yearly reports of the Orthodox Missionary Society, and the reports of individual missions and missionary establishments" (A Short Account of the Historical Development and Present Position of Russian Orthodox Missions [London, 1903; repr., Willits, Calif.: Eastern Orthodox Books, n.d.], p. 11).

22. Ibid.

23. Zernov, The Russians and Their Church, p. 60.

24. Nadejda Gorodetzky, "The Missionary Expansion of the Russian Orthodox Church," International Review of Missions 31 (1942): 402.

25. C. Samuel Calian, "Eastern Orthodoxy's Renewed Concern for Mission," International Review of Missions 52 (1963): 35.

26. James J. Stamoolis, Eastern Orthodox Mission Theology (Maryknoll, N.Y.: Orbis Books, 1986), p. 28.

27. K. S. Latourette, A History of the Expansion of Christianity, 7 vols. (London: Eyre \& Spottiswoode, 1947), 3:76-77.

28. This role was to be maintained for the next century where the church was seen as a practical administrator of the colonized regions. See Kobtzeff, "Ruling Siberia," pp. 276-79.

29. Andrei A. Znamenski, Shamanism and Christianity: Native Encounters with Russian Orthodox Missions in Siberia and Alaska, 1820-1917 (Westport, Conn: Greenwood Press, 1999), p. 4.

30. Lapidus, History of Islamic Societies, p. 423.

31. Collins, "Colonialism and Siberian Development," p. 54.

32. Smirnoff, Short Account, p. 15;Znamenski, Shamanismand Christianity, p. 4 .

33. C. R. Bawden, Shamans, Lamas, and Evangelicals (London: Routledge \& Kegan Paul, 1985), p. 244.

34. Stamoolis, Eastern Orthodox Mission Theology, p. 29; Collins, "Colonialism and Siberian Development," p. 54. Many clergy were actually supporting this apostasy; see Znamenski, Shamanism and Christianity, p. 65.

35. Smirnoff, Short Account, pp. 28-29.

36. There seems to be some disagreement over Makarii's date of death: Stamoolis (Eastern Orthodox Mission Theology, p. 28), Gorodetzky ("Missionary Expansion," p. 407), and Zernov (Eastern Christendom, p. 181) suggest 1847, while Nikita Struve ("Macaire Gloukharev, a Prophet of Orthodox Mission," International Review of Missions 54 [1965]: 314) suggests April 18, 1849.

37. Struve, "Macaire Gloukharev," p. 309; Stamoolis, Eastern Orthodox Mission Theology, p. 28.

38. Zernov, Eastern Christendom, p. 163.

39. Struve, "Macaire Gloukharev," p. 310.

40. Zernov, Eastern Christendom, p. 181. There seems to be some discrepancy in the dates for the beginning of the mission. Gorodetzky ("Missionary Expansion," p. 407) suggests 1828, while Georges Florovsky ("Russian Missions: An Historical Sketch," in Aspects of Church History [Belmont, Mass.: Nordland Publishing, 1975], p. 148) agrees with Zernov in suggesting 1830 . I think 1830 is more plausible, given the time needed between the initial appeal and the starting of a mission.

41. Florovsky, "RussianMissions," p.148;Struve, "MacaireGloukharev," p. 311.

42. Florovsky, "Russian Missions," p. 148.

43. This language learning was reflective of the priority that the Orthodox Church has given to "indigenization of the faith." See Ion Bria,
"Introduction," in MartyriaMission: The Witness of the Orthodox Churches Today, ed. Ion Bria (Geneva: WCC Publications, 1980), pp. 10-11.

44. Zernov, Eastern Christendom, p. 181.

45. Struve, "Macaire Gloukharev," p. 311.

46. Makarii Gloukharev, quoted in ibid.

47. Ibid., p. 312

48. Gorodetzky, "Missionary Expansion," p. 407.

49. Struve, "Macaire Gloukharev," p. 312.

50. Florovsky, "Russian Missions," p. 148; Struve writes that it was 674 over fourteen years ("Macaire Gloukharev," p. 312).

51. Smirnoff, Short Account, p. 18.

52. Stamoolis, Eastern Orthodox Mission Theology, pp. 30, 31.

53. Florovsky, "Russian Missions," p. 149.

54. Zernov, Eastern Christendom, p. 181.

55. Struve, "Macaire Gloukharev," p. 314.

56. Latourette, Expansion, 4:121-22.

57. By the end of his life Ilminskii was able to speak Hebrew, Greek, Latin, Arabic, Persian, Tatar, Cherimis, Chuvash, Mordvin, Kirghiz, Yakut, and several other Siberian languages. See Zernov, Eastern Christendom, p. 183.

58. Latourette, Expansion, 4:122.

59. Stamoolis, Eastern Orthodox Mission Theology, p. 32.

60. Florovsky, "Russian Missions," p. 153.

61. Ibid.; Zernov, Eastern Christendom, p. 183.

62. Quoted in Smirnoff, Short Account, p. 33.

63. Gorodetzky, "Missionary Expansion," p. 408.

64. Stamoolis, Eastern Orthodox Mission Theology, p. 32.

65. George Robinson, "The Mission of Nikolai Il'Minskii, Lay Missionary of the Russian Orthodox Church (1821-1891)," International Journal of Frontier Missions 7, no. 3 (July 1990): 78.

66. Florovsky, "Russian Missions," p. 154. One of Ilminskii's Tatar assistants won a large following through the use of the vernacular. Latourette mentions that this man banded his listeners together in order to form choirs singing Christian hymns (Expansion, 4:122).

67. S. Bolshakoff, "Orthodox Missions Today," International Review of Missions 42 (1953): 277.

68. Zernov, Eastern Christendom, p. 183.

69. Smirnoff, Short Account, p. 33.

70. Ilminskii, as quoted in ibid., p. 34.

71. Florovsky, "Russian Missions," p. 153.

72. Znamenski, Shamanism and Christianity, p. 63.

73. Stamoolis, Eastern Orthodox Mission Theology, p. 32.

74. Znamenski, Shamanism and Christianity, p. 63.

75. Bolshakoff, "Orthodox Missions Today," p. 277.

76. Florovsky, "Russian Missions," p. 145.

77. Bolshakoff, "Orthodox Missions Today," p. 277.

78. Zernov, Eastern Christendom, p. 183.

79. Florovsky, "Russian Missions," p. 154.

80. Zernov, Eastern Christendom, p. 183. According to Johannes Reimer, the Mordvin, the Chuvash, and the Cheremi are still considered to be primarily Orthodox in faith, though highly nominal (Operation Soviet Union: How to Pray for the 160 People Groups in the USSR [Fresno, Calif.: Logos, 1988, 1990]).

81. Smirnoff, Short Account, p. 70.

82. Znamenski, Shamanism and Christianity, p. 60.

83. Smirnoff, Short Account, p. 52.

84. Znamenski, Shamanism and Christianity, p. 60.

85. Smirnoff, Short Account, pp. 52-53.

86. See ibid., pp. 62-74, for his more detailed outline.

87. Ibid., p. 63.

88. Collins, "Colonialism and Siberian Development," pp. 57-58.

89. Smirnoff, Short Account, p. 62.

90. Ibid., pp. $69-70,73$. 